\title{
Hawaiian Limpet Harvesting in Historical Perspective: A Review of Modern and Archaeological Data on Cellana spp. from the Kalaupapa Peninsula, Moloka'i Island ${ }^{1}$
}

\author{
Mark D. $M c C o y^{2}$
}

\begin{abstract}
The isolated Kalaupapa region, Moloka'i Island, Hawai'i, offers archaeologists and ecologists a unique opportunity to study traditional Hawaiian limpet ('opihi) (Cellana spp.) harvesting from the Proto-Historic Period (16501795), Early Historic Period (1795-1866), and the present day. In this study, archaeological collections, modern harvests, and field observations are used to describe a regular pattern of slightly larger mean limpet size in western shoreline harvests and an increase in average limpet size from the Proto-Historic Period to the present. Although further investigations are necessary to test alternative explanations, these results suggest (1) that shelter from ocean currents and trade winds may provide a microenvironment favorable to local limpet growth, and (2) a lessening of harvesting pressure concurrent with the massive depopulation of the study area after European contact. Future studies should focus on identifying possible ecological factors impacting average size, documenting changes in limpet size using specimens from archaeological deposits, and accounting for the impact of population change on marine resources in historic and prehistoric Hawai'i.
\end{abstract}

Although archaeological studies of the Kalaupapa region, Moloka'i Island, Hawaici, have been successful at tracking prehistoric expansion and intensification of agriculture (Kirch 2002, Kirch et al. 2003, McCoy 2005a, McCoy and Hartshorn 2007), there is little notion of what impact, if any, past human occupation had on marine resources. Harvested shellfish are often a major component of archaeological deposits worldwide, especially in thick deposits built up over time from persistent discard in the same location, commonly referred to as shell middens (see Bowdler 2006 for a recent review); how-

${ }^{1}$ This work was supported by the National Science Foundation (BSC-0535706), the Arizona Memorial Museum Association, and the National Park Service. Manuscript accepted 20 February 2007.

${ }^{2}$ Department of Anthropology and Behavioral Sciences, One Washington Square, San Jose State University, San Jose, California 95192-0113 (phone: 408924-5542; e-mail: mdmccoy@email.sjsu.edu).

Pacific Science (2008), vol. 62, no. 1:21-38

(C) 2008 by University of Hawai'i Press

All rights reserved ever, the analysis of these remains by archaeologists has been plagued by problematic working assumptions (Erlandson 1988, Claassen 1998, Jackson et al. 2001, Mannino and Thomas 2002). Until recently, it was commonplace for archaeologists to assume that shellfish had never made a substantial contribution to paleodiet and were best categorized as a "starvation food" or a "seasonal resource" (Erlandson 1988:102). More recently, when archaeological analyses have detected a diminished abundance, reduced mean size, or extinction of shellfish, these are unproblematically interpreted as evidence of human overexploitation (Claassen 1998, Bowdler 2006:334). On the other extreme, there is the equally pervasive and problematic myth of the "ecological Indian," which assumes that prehistoric peoples were unfailing ecological stewards who never overexploited natural resources (Krech 1999, Kirch 2005:423). However, these fallacies are slowly being debunked, and in their place researchers are simultaneously considering environmental factors that impact shellfish populations (Jerardino 1997), variation in human harvesting and discard behavior (Bird 
and Bird 1997, Bird et al. 2002), and paleodemography (Klein 1999:470-471) as potentially accounting for patterns observed.

In their recent review, Jackson et al. (2001) distinguished between three overlapping chapters in the history of human impact on marine resources: aboriginal, colonial, and global periods. Each period is characterized by different extractive technologies, economic motivations, and types of resource management. The authors noted that to take this kind of historical perspective one must "sacrifice some of the apparent precision and analytical elegance prized by ecologists" and use paleoecological, archaeological, and historical records (Jackson et al. 2001:630). Indeed, there is an overall trend toward a closer relationship between archaeology and ecology, especially with the explicit use of optimal foraging models to interpret faunal remains from archaeological deposits. Unfortunately, these studies have been narrowly focused on prehistoric aboriginal harvesting and rarely address the historic period. Further, Mannino and Thomas (2002:458) noted that there are "problems in using optimal foraging models as the primary basis for inferring over-exploitation ... [because] human foraging strategies and processing decisions can have a marked impact on what is incorporated into a developing midden" (see also Bird and Bird 1997, Bird et al. 2002). Nonetheless, foraging efficiency, diet breadth, and overexploitation are important factors in evaluating marine resource use over time.

\section{Previous Research on Cellana spp.}

Known locally as 'opibi, Cellana spp. are a collection of several shellfish species endemic to the Hawaiian Islands, including $C$. exarata (blackfoot), C. sandwicensis (yellowfoot), and C. talcosa (giant 'opibi) (Kay and Magruder 1977). These limpets occupy overlapping basalt shore habitats in the intertidal and subtidal coastal zones, with $C$. exarata preferring the splash zone close to the shore, $C$. sandwicensis slightly farther away, and the larger $C$. talcosa living farthest from the coast in the low littoral and sublittoral zones at depths up to $10 \mathrm{~m}$ below sea level (Magruder and Kay
1983). Much of what is known about the biology of Cellana spp. comes from studies conducted in the 1970s by Kay and Magruder (1977), who used a combination of data from collected specimens, harvests, and archaeological collections to describe Hawaiian limpet biogeography and growth rates and to demonstrate a relationship between commercial harvesting pressure and average size.

\section{The Kalaupapa Region, Moloka'i Island}

Located on Moloka'i Island's rugged north shore, the Kalaupapa region includes more than $14.7 \mathrm{~km}$ (9.1 miles) of shoreline that ranges from sand beaches on Kalaupapa Peninsula's western and northern coasts to high eastern basalt benches and boulder beaches along the base of sea cliffs (Figure 1). The coastline in the eastern half of the study area is directly exposed to trade winds and currents that create a high-energy sea spray zone year-round (Canfield 1990). Indeed, ocean travel along this coast is virtually impossible during the winter months due to high swells.

In 1866, the Kingdom of Hawai'i's Board of Health took advantage of the Kalaupapa Peninsula's natural isolation to resettle people with Hansen's disease (leprosy). Today, the area is designated as a national historical park and managed through a partnership between the State of Hawai'i's Department of Health and the U.S. National Park Service. The former cares for the local community's last remaining Hansen's disease patients and the National Park Service manages cultural and natural resources (Alexander 1996).

Recent archaeological research in Kalaupapa has been centered on defining a history of social development from A.D. 800 to the foundation of the Hansen's disease settlement in the midnineteenth century (Kirch 2002, McCoy 2002, 2003, 2004, 2005a,b, 2006). In brief, these studies suggested that the first secure signs of settlement and agricultural activities are in wetland environments, specifically in local valleys and at the bases of cliffs, and date to around A.D. 1150-1200 (McCoy 2005a). Nonirrigated farming was strictly limited at first, but after A.D. $1450-1550$ there are clear signs of the 


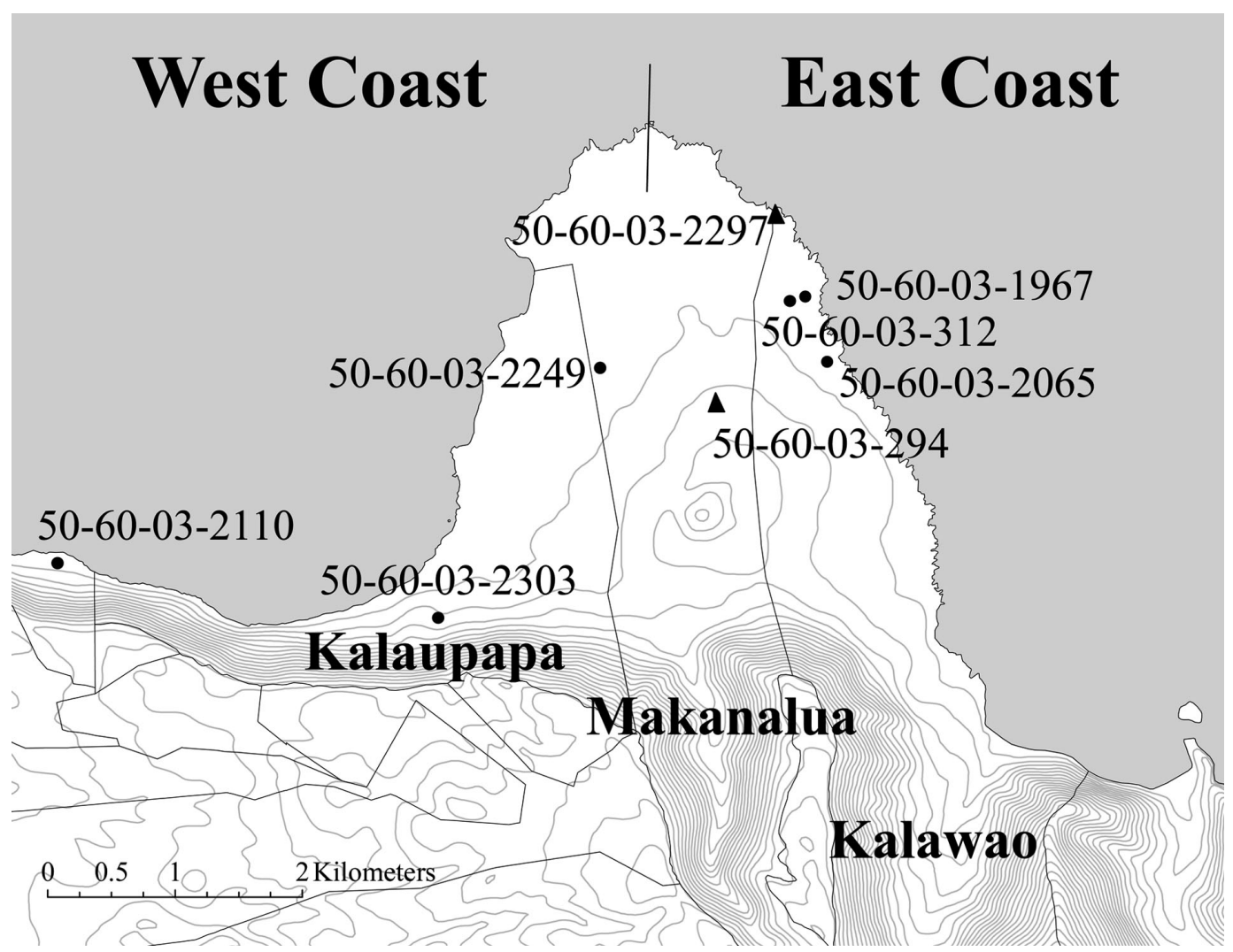

Figure 1. Kalaupapa region, Moloka'i Island, Hawai'i. Bold lines indicate community territory (ahupua'a) boundaries. Archaeological sites are labeled with State of Hawai'i Register of Historic Places identification numbers. Sites include habitations (circles) and ritual sites (triangles); 100-foot elevation contours are shown.

development of a large-scale agricultural field system that occupied the entire Kalaupapa Peninsula (Kirch 2002, McCoy 2005a). However, it was not until after A.D. 1650 that settlement expanded onto the peninsula itself. Oral traditions suggest that it was also at that time that a local chiefdom centered on the northern half of the island was subjugated by its rivals and a monument to this defeat built in the center of the peninsula (McCoy 2005b, Manning and Neller in press).

\section{Previous Archaeological Research}

Archaeologists throughout Oceania rely on shellfish remains to help reconstruct ancient diet (see Kirch [2000] for a recent review of Oceanic prehistory). In the Kalaupapa region, excavations at a cave shelter in the late 1960s were specifically aimed at using shellfish remains to learn more about local resource use (Kaupikiawa Cave, State of Hawaii Register of Historic Places ID number 50-60-03-312 [Hirata and Potts 1967, Pearson et al. 1974]). Of the five taxa described in postfieldwork analysis, sea snail (Neritidae) and limpet (Cellana spp.) were selected to test changes in the average size of individuals over time. In this case, change in size was determined by counting the number of specimens per $200 \mathrm{~g}$ of shell remains. Contrary to their expectations, the team found that shellfish increased in average size over time. Although they had no notion of the actual date of the site's use, they suggested that the pattern "might be inferred to reflect a lessening of the pressure on the 
shell[fish] supply during the time period of the upper levels" (Pearson et al. 1974:48). However, it remained undetermined if the trend was "the result of human activity relating to the shellfish or to an internal dynamic within the shell[fish] population" (Pearson et al. 1974:49).

In 2000, Kirch (2002) revisited that cave site and made small, column samples of deposit left exposed by the previous project's excavation pits. Next, modern sediment analyses and radiocarbon dates were used to establish a firm site chronology (Kirch et al. 2003). Several new radiocarbon dates (accelerated mass spectrometry) on individual fragments of charcoal identified as short-lived species helped determine that the lowest artifact-free deposits in the cave marked burning in the area associated with initial dryland cultivation beginning in the twelfth century A.D. Next, sometime after A.D. 1650 , the site began to be used as a shelter, possibly as part of a larger house complex (Kirch et al. 2003). Finally, the discovery of metal and glass artifacts in the uppermost levels showed that the occupation of the site continued into the Early Historic Period.

Most important for this study, Kirch et al. (2003:16-19) made a thorough evaluation of the variety and amounts of food remains present, specifically noting that invertebrate and vertebrate species contributed roughly equal amounts of the biomass represented, that density of invertebrate remains (the number of individual specimens per cubic centimeter excavated) was highest at initial occupation and decreased, and that C. sandwicensis predominated over other Cellana spp. The first observation is consistent with interpretations of the area around the site as a commoner household located near the coast. At such a site we would expect fish and shellfish to be regularly consumed, with domesticates, such as pig, reserved for higher-status peoples or ceremonial occasions (Kirch and O'Day 2003). The second pattern, decreasing density of shellfish remains, suggests a trend toward less-abundant marine resources after the initial occupation of the site sometime after A.D. 1650.

Finally, Kirch et al. (2003) suggested that the virtual absence of one of the two common nearshore limpets "may be indicative of over-exploitation of $C$. exarata prior to the occupation of the rockshelter" or simply "selective emphasis" on C. sandwicensis (Kirch et al. 2003:17). Although it is difficult to determine definitively if overexploitation or selective preference is responsible for this pattern, an analysis of invertebrate taxa suggests that diversity is primarily a function of the abundance of shellfish in the layer examined and that harvesting behavior has been relatively stable over time (Figure 2) $\left(r^{2}=0.59\right)$.

\section{MATERIALS AND METHODS}

Although the overall goal of this study is the reconstruction of traditional Hawaiian subsistence patterns, modern and archaeological data on limpets (Cellana spp.) play an equally important role in the analysis. Thus, each data set is described in the following sections.

\section{Modern Data Collection}

In the past decade, the Hawai'i State Department of Health has banned shellfish gathering by visitors to the Kalaupapa region. Thus, collecting has been limited to perhaps less than 100 people, including Kalaupapa community residents and other local Moloka'i Island residents accessing the area by small boat. From 2002 to 2004, the natural resources division of Kalaupapa National Historical Park took advantage of these low levels of harvesting to document Cellana spp. population biology through two methods: field examinations of shellfish and tracking the size of shellfish harvested by local gatherers (Hughes and Carnevale 2004). Gatherers were explicitly asked to report the location of their catch and when during the year they were collected. Following Kay and Magruder (1977), shellfish were sorted by size in $5 \mathrm{~mm}$ categories and converted into percentages by size class. Inspections of shellfish in the field were made without removing individual animals and then also converted into size classes.

Field observations made in the study's first year centered on two boulder beaches on the 


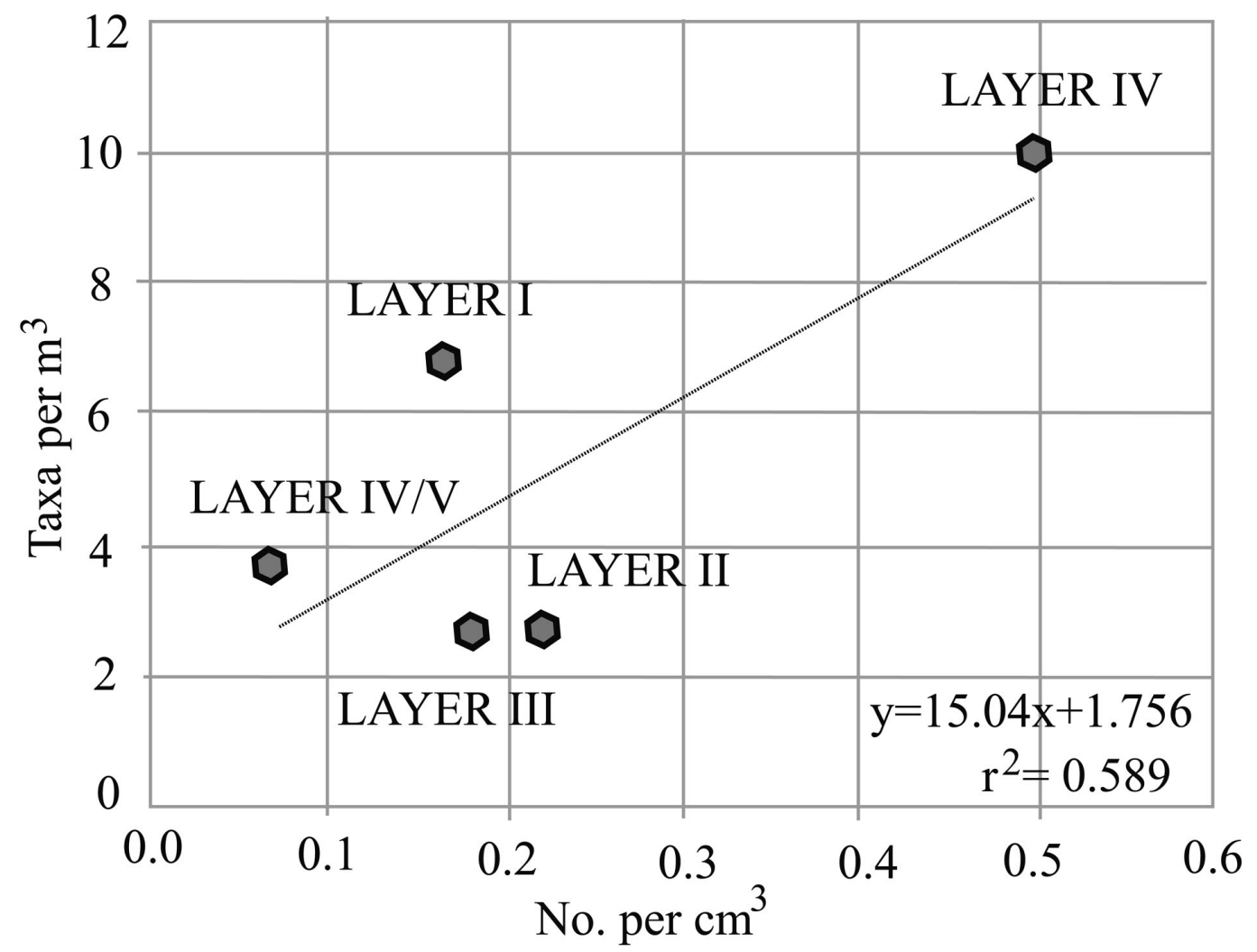

Figure 2. Diversity-abundance index of invertebrates, Kaupikiawa Cave, Hawai'i. $X$-axis shows abundance (density of invertebrates [number of identified specimens] per cubic centimeter) and $y$-axis shows taxa diversity (number of identified invertebrate taxa per cubic meter). Note that the diversity is primarily accounted for by the abundance of invertebrates in deposits, suggesting that harvesting behavior varied little from the Proto-Historic through Early Historic Periods. (Source: Kirch et al. 2003: table 3.)

western portion of the study area specifically chosen to measure populations at the end of the harvest season in easily accessible locations. At each of these locations, subplots, or points, were marked and numbered one through six. Recording began at the top of the coralline algae zone and plots were set $50 \mathrm{~m}$ apart along the shoreline. At each point chalk lines were drawn in cardinal directions, and within the quadrants formed shellfish length on 138 specimens was measured to the nearest millimeter. Next, a point center quarter method was used to evaluate limpet density (Hughes and Carnevale 2004).

Field observations in the project's second year expanded to include transects within 18 coastal subsections (Hughes and Carnevale 2004). Within each section, two randomly placed transects were set at the top of the spray zone at the first Cellana sp. encountered. Recording proceeded in a band $0.6 \mathrm{~m}$ wide and ended when no more individuals were found. Total count, length, and width were reported at the species level. In the analysis presented here transect data have been particularly valuable in quantifying intraregional differences in average sizes of $C$. exarata and C. sandwicensis. Overall, in the project's second year 152 specimens were measured in the field and 3,448 harvested shellfish were cataloged.

In the project's third year 1,996 harvested 
TABLE 1

Summary of Archaeological Site Excavations, Kalaupapa Region, Hawai'i

\begin{tabular}{llcll}
\hline \hline $\begin{array}{l}\text { Community } \\
\text { Territory }\end{array}$ & $\begin{array}{c}\text { Site } \\
\text { Function }\end{array}$ & $\begin{array}{c}\text { State } \\
\text { Site No. }\end{array}$ & \multicolumn{1}{c}{ Layer/Level } & Era \\
\hline Kalaupapa & Habitation & 2110 & I/2 to I/4 & Proto-Historic (A.D. 1650-1795) \\
Kalaupapa & Habitation & 2110 & I/1 & Early Historic (A.D. 1795-1866) \\
Kalaupapa & Habitation & 2303 & I/1 to I/2 & Expansion Period (ca. A.D. 1150) \\
Makanalua & Ritual & 294 & I/1 to II/4 and Fea. 1 & Traditional Era (A.D. 800-1795) \\
Makanalua & Habitation & 2249 & I/1 to II/2 & Proto-Historic (A.D. 1650-1795) \\
Makanalua & Ritual & 2297 & I/1 to II/3 & Traditional Era (A.D. 800-1795) \\
Kalawao & Habitation & 2065 & I/1 to II/2 & Proto-Historic (A.D. 1650-1795) \\
Kalawao & Habitation & 1967 & I/1 to I/2 & Early Historic (A.D. 1795-1866) \\
\hline
\end{tabular}

Source: McCoy (2003, 2004).

shellfish were sorted by size, bringing the total number of modern Cellana spp. specimens studied to date to 5,734 (Hughes and Carnevale 2004).

\section{Archaeological Data Collection}

To represent ancient harvests whole Cellana spp. specimens were drawn from archaeological collections representing sites across the Kalaupapa region (McCoy 2003, 2004) (Figure 1, Table 1). Excavation methodology at those sites employed arbitrary levels within natural layers that were dated using accelerated mass spectrometry (AMS) radiocarbon dating of charcoal and/or the presence of historic materials (metal, glass, ceramics). Excavations targeted floor deposits or food rubbish dumps assumed to represent multiple years of harvesting. Table 1 shows the depth, interpretation, and age of deposits.

Shellfish collections include a proportionately large number of specimens from two habitation sites dated to a time in Hawaiian culture history called the Proto-Historic Period (A.D. 1650-1795). One site is located on the Nihoa Landshelf (50-60-03-2110) $(n=87)$, and the other is on the eastern coast near the transition from high bench to boulder beach (50-60-03-2065) $(n=48)$ (Figure 1). Smaller amounts of Cellana spp. were also found in several sites in the center of the peninsula, including a temple (beiau) (50-60-03294) $(n=48)$, a structure interpreted as a shrine (50-60-03-2297) $(n=16)$ on the border between two communities, and a simple house site (50-60-03-2249) $(n=20)$ likely occupied in the past by commoner-class people. In addition, at a site in the western community territory (abupua'a) called Kalaupapa several large specimens (C. talcosa) were found intentionally placed under floor paving stones (50-60-03-2303). Historic-Period collections include a large number of shellfish from two habitation sites including later-period deposits at the same site referred to earlier on the Nïhoa Landshelf (50-60-03-2110) $(n=121)$ and a different eastern-coast house site adjacent to high-bench shoreline (50-60-031967) $(n=36)$.

The length of specimens was measured by caliper, converted into $5 \mathrm{~mm}$ size categories, and reported as percentages by size class. Because archaeological collections lacked distinguishing color markings due to their age, only C. talcosa could be identified reliably. In total, 381 individual specimens from archaeological collections were examined for this study.

\section{RESULTS}

Results of analysis are presented here in terms of two empirical questions: (1) What geographic variability is evident in modern $\mathrm{Cel}$ lana spp. within the study area? and (2) How has average Cellana spp. length changed over the last $350 \mathrm{yr}$ ? 
TABLE 2

Shellfish Average Widths

\begin{tabular}{lcc}
\hline \hline & \multicolumn{2}{c}{ Average Size (mm), SD } \\
\cline { 2 - 3 } Cellana spp. & Western Kalaupapa Peninsula & Eastern Kalaupapa Peninsula \\
\hline Summary & $27.4,5.6$ & $24.3,5.3$ \\
$\quad$ A.D. 1650-1795 & $32.7,7.3$ & $28.7,8.6$ \\
A.D. 1795-1866 & $42.8,7.4$ & $32.5,8.2$ \\
A.D. 2004 & $(n=96) 27.6,8.6$ & $(n=77) 19.2,6.6$ \\
Modern & $(n=56) 32.0,10.0$ & $(n=50) 27.6,11.5$ \\
$\quad$ C. exarata & & \\
C. sandwicensis &
\end{tabular}

Sources: Hughes and Carnevale (2004), McCoy (2006).

\section{Cellana spp. Geographic Variation}

Because of the stark ecological contrast between the western and eastern coastlines of the Kalaupapa Peninsula, field observations were used to test for species-specific variation in average size. In this analysis, C. exarata and C. sandwicensis data from Hughes and Carnevale's (2004) 2003 field transects were chosen specifically because these were the only species observed on both coasts that season. On the western coast $C$. exarata $(n=96$; $27.6 \mathrm{~mm}$; SD [standard deviation] 8.6) specimens were found to be slightly larger on average than eastern-coast populations $(n=$ 77; $19.2 \mathrm{~mm}$; SD 6.6) (Figure 1, Table 2). Cellana sandwicensis on the western coast $(n=56$; $32 \mathrm{~mm}$; SD 10.0) were again larger than C. sandwicensis on the east coast $(n=50$; $27.6 \mathrm{~mm}$; SD 11.5). Although these are clearly overlapping distributions, a $t$-test showed differences between comparable western and eastern populations in both $C$. exarata $(t=3.92, \mathrm{df}=21, P=.001)$ and $C$. sandwicensis $(t=1.43, \mathrm{df}=47, P=.20)$.

When we look at the size distributions of modern harvested Cellana spp. (our best ana$\log$ for prehistoric shellfish gathering) we also find that catches from the same year vary due to location. Figure 3 shows that not only are western harvest samples larger than eastern, but they are larger beyond even what one would expect based on the slight average difference within species discussed earlier. Al- though these catches were not sorted by species in the original study, it is likely that this discrepancy between average sizes is due to a combination of the location-specific within-species variation and a greater proportion of larger species of Cellana spp. in the west-coast harvest. This would be consistent with the 2003 season survey in which C. tal$\cos a(n=20)$, which is rarer but larger than both C. exarata and C. sandwicensis (Kay and Magruder 1977), was reported only on the sheltered west coast.

Overall, it appears that modern limpet populations can vary from one coast to another within the study area. An analysis of Hughes and Carnevale's (2004) data show west-coast $C$. exarata just over $8 \mathrm{~mm}$ larger than their east-coast neighbors and C. sandwicensis over $4 \mathrm{~mm}$ larger than neighboring eastern-coast populations. When modern harvests that include a range of species are compared, there is also a marked difference between average sizes in different locations. This later pattern is likely due in part to natural variability within species and the higher likelihood that larger species will appear in western-coast harvests.

\section{Tracking Changes in Average Size over Time}

When all available data are considered together, specifically archaeological and modern harvest data, it is possible to track changes 


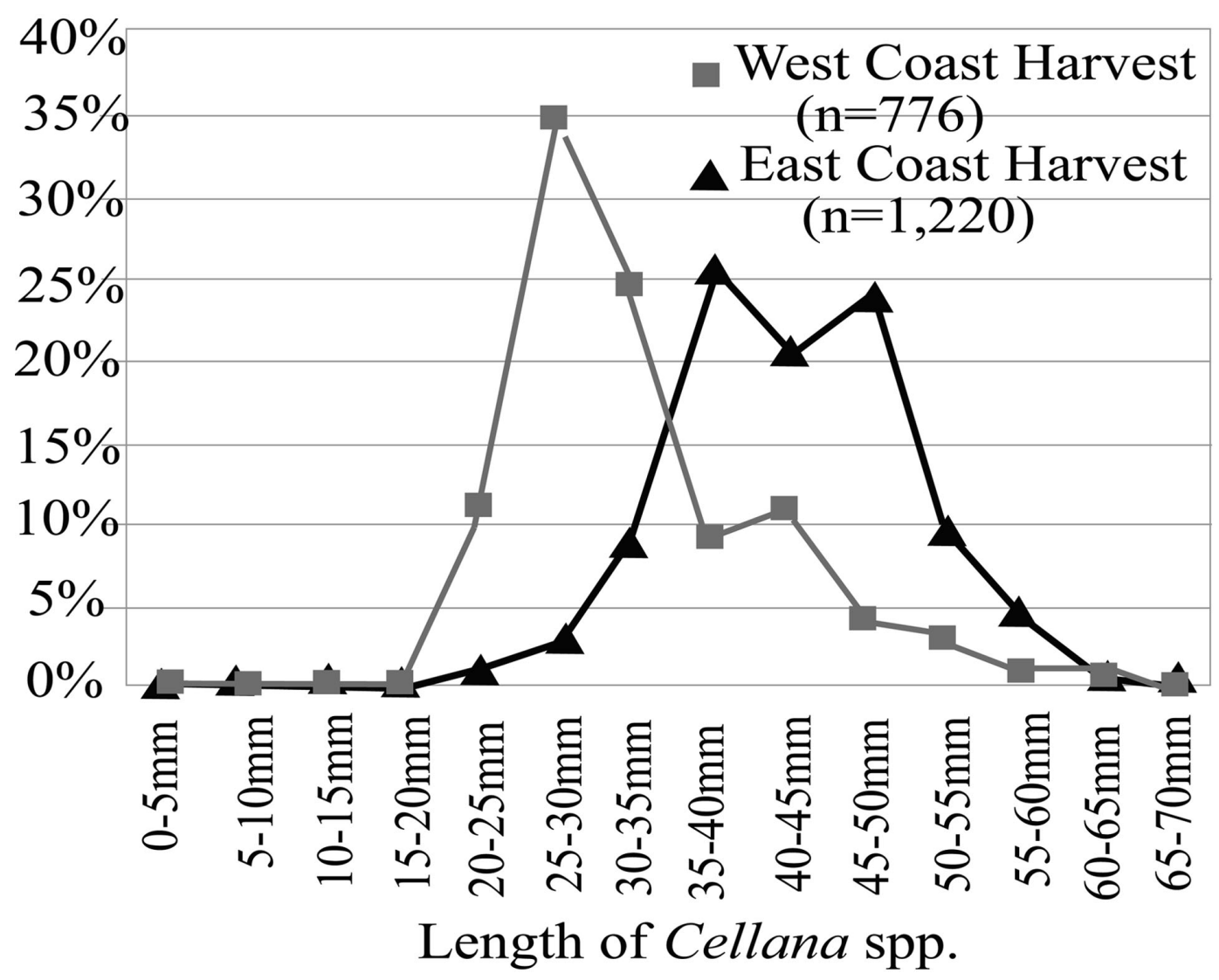

Figure 3. Comparison of 2004 Cellana spp. harvest size distributions, Kalaupapa region, Moloka'i Island; 5 mm size classes shown. (Source: Hughes and Carnevale 2004.)

in shellfish populations over three chronological phases (Table 2). The earliest time period represented in collections, called here "Phase $1, "$ corresponds to deposits dating to the Proto-Historic Period (A.D. 1650-1795). The next phase, "Phase 2," includes shellfish deposited in the Early Historic Period (A.D. 1795-1866) before the construction of the local Hansen's disease settlements. Finally, "Phase 3" is the modern era as represented by 2004 summer harvest data. In addition, it should be noted that the observations chosen to represent the modern period are appropriate for comparison with archaeological data because they represent "mid-harvest" size distribution profiles rather than the extremes of annual population size variation.
If we begin by examining regional average size we find an increase of about $5 \mathrm{~mm}$ between periods (average size in Phase 1: $25.4 \mathrm{~mm}$; Phase 2: $31.8 \mathrm{~mm}$; and Phase 3: $36.7 \mathrm{~mm}$ ). However, this measure alone does not allow us to account for the natural interregional difference in shellfish size described earlier. In the modern data set, investigators controlled for location of shellfish collection (e.g., $n=776$ were collected from the western shore and $n=1,220$ from the eastern shore). In the archaeological data sets, it is virtually impossible to determine with absolute certainty the source of specimens recovered from sites. Nonetheless, if we assume that most shellfish were collected locally from the closest shoreline, an assumption that 


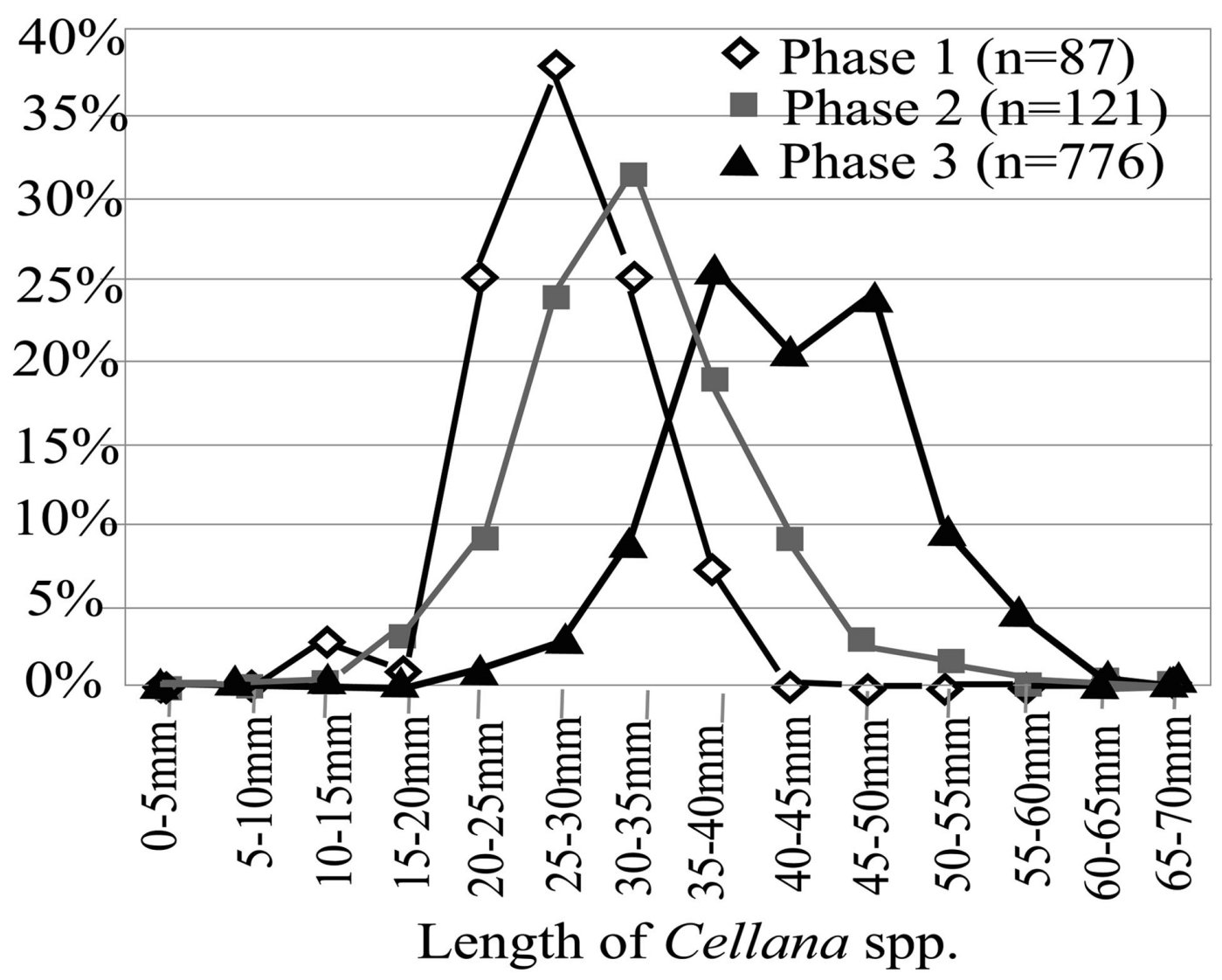

Figure 4. Long-term Cellana spp. population dynamics, West Kalaupapa region, Moloka'i; $5 \mathrm{~mm}$ size classes shown. Phase 1, Proto-Historic Period (A.D. 1650-1795); Phase 2, Early Historic Period (A.D. 1795-1866); Phase 3, Modern Period (A.D. 2004). (Sources: Hughes and Carnevale 2004, McCoy 2006.)

ideally should be tested in future using independent data, then it is possible to tentatively group prehistoric and historic-period collections by shoreline (e.g., in Phase 1, $n=87$ assigned to the western shore, $n=$ 68 to the eastern shore; in Phase 2, $n=121$ assigned to the western shore, $n=36$ to the eastern shore). Following this grouping, observed modern interregional size difference was used as a benchmark to assess the degree of geographic segregation represented. This was based on the assumption that if shellfish from archaeological sites are dominated by local catches, then the difference between western and eastern sites should be similar to the observed modern average difference in directionality (i.e., western larger than eastern shellfish) and degree (i.e., ca. 3-10 mm difference in average size). In all, it appears that these groupings are reasonable, if imperfect, proxy evidence for local catches because in both prehistoric and historic deposits western shellfish are larger than eastern shellfish and this size difference is within the low end of the range observed in modern catches (i.e., 3-4 mm).

Finally, we again find a steady increase in Cellana spp. size from Phase 1 to 3 when samples are divided by coastline (Figures 4 and 5). On the western coast, average size shifts from $27.4 \mathrm{~mm}$ (SD 5.6) in the first phase, to $32.7 \mathrm{~mm}$ (SD 7.3) in the second, to $42.8 \mathrm{~mm}$ (SD 7.4) at the current time (Figure 4). On the eastern coast, average size increases from 


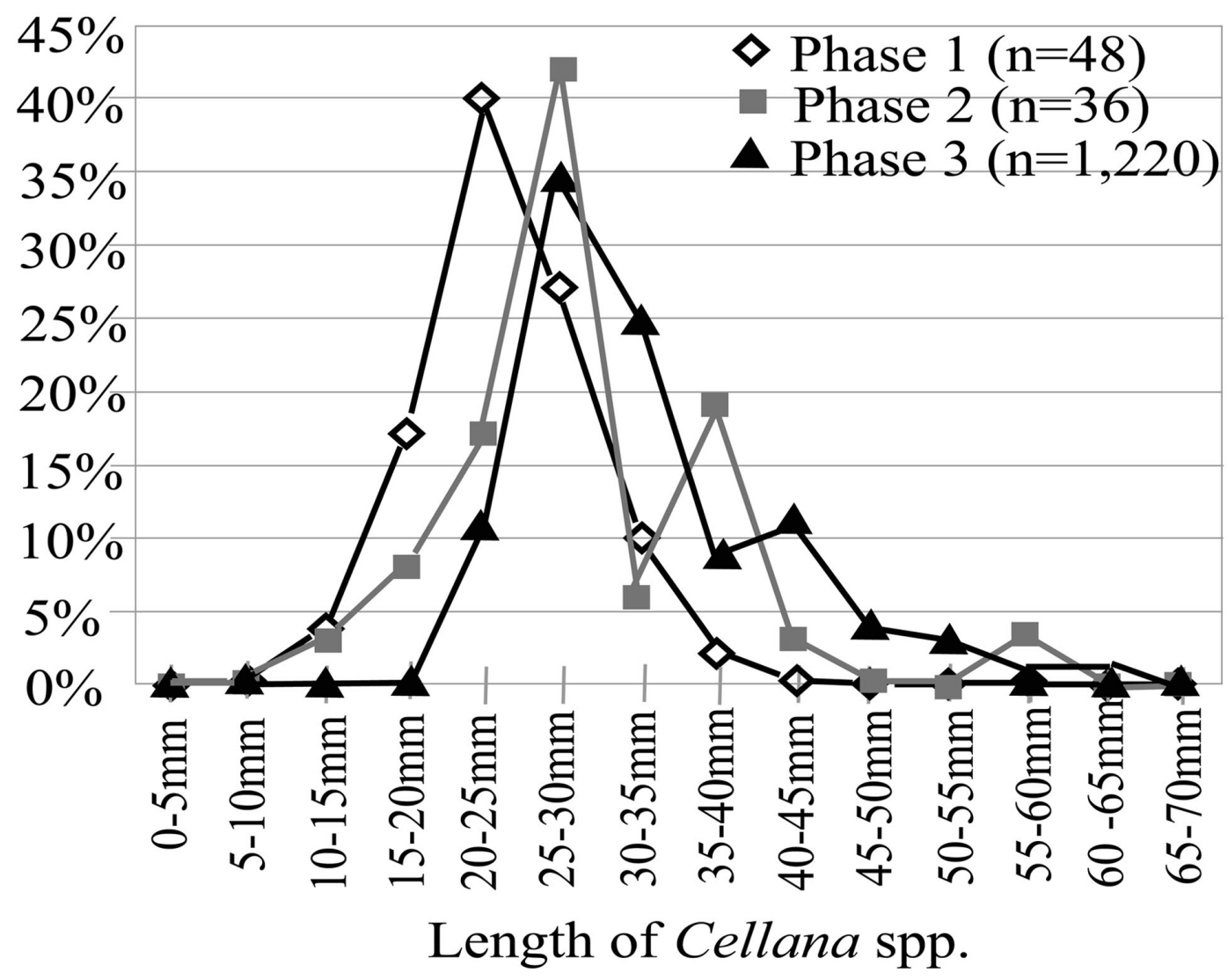

Figure 5. Long-term Cellana spp. population dynamics, East Kalaupapa region, Moloka'i; 5 mm size classes shown. Phase 1, Proto-Historic Period (A.D. 1650-1795); Phase 2, Early Historic Period (A.D. 1795-1866); Phase 3, Modern Period (A.D. 2004). (Sources: Hughes and Carnevale 2004, McCoy 2006.)

$24.3 \mathrm{~mm}$ (SD 5.3) in the first phase, to $28.7 \mathrm{~mm}$ (SD 8.6) in the second, to a current average size of $32.5 \mathrm{~mm}$ (SD 8.2) (Figure 5). $T$-tests show that although these size distributions overlap, they are statistically distinct when comparing averages over time within areas (West: Phase 1 to $2: t=5.7, \mathrm{df}=210$, $P=.001$; Phase 2 to $3: t=14.2$, $\mathrm{df}=898$, $P=.001$; East: Phase 1 to $2: t=2.9, \mathrm{df}=$ $83, P=.001$; Phase 2 to $3: t=3.0, \mathrm{df}=$ $1,254, P=.001)$ and comparing western to eastern populations (Phase 1: $t=3.3$, df $=$ 137, $P=.001$; Phase 2: $t=2.7, \mathrm{df}=156$, $P=.001 ;$ Phase $3: t=27.5, \quad \mathrm{df}=1,996$, $P=.001)$.

\section{DISCUSSION}

The following discussion focuses on the possible ecological, behavioral, and demographic explanations for the patterns observed, specifically the discovery of larger average-sized limpets on the western coast of the study area and the overall increase in average limpet size from roughly A.D. 1650 to the present.

\section{Ecological Variables}

Although this study was not undertaken to specifically identify ecological variables that may, or may not, inhibit and promote Hawai- 
ian limpet (Cellana spp.) growth, it is important to qualify the study's findings in terms of ecological variables that may influence growth: water turbidity and soil erosion, sea surface temperature, and sea level and shoreline change.

First, water turbidity and soil erosion from terrestrial sources are considered in concert here because they share the same vector of potential impact on limpet growth-an increase in the inorganic content of water. Previous studies have linked increases in inorganic material in water with increased energy expenditure on separating out nonnutritious from nutritious material, in some cases resulting in smaller-sized limpets (Griffiths 1980). In the study area, there are two major factors impacting ocean water turbidity at any one time and place: seasonal variation and level of exposure to ocean currents and trade winds. In this regard, although both coasts have turbulent winter seas, the western coast has greater natural shelter from northeastern trade winds and currents provided by the Kalaupapa Peninsula. In their recent study of Kalaupapa limpets, Kay et al. (2005) tentatively linked local ocean conditions on the western coast and limpet growth. They (Kay et al. 2005:6-7) described the area as "unique, in that it is generally tidally dominated in the summer, being protected from trade winds. In the winter, it is fully exposed to the Northwest swell.... The proportion of spent $C$. exarata and $C$. sandwicensis at KALA during the initial sampling was 0.6 and 1.0 , respectively, and much greater than that at the other sites. This indicates that a major spawning event preceded the initial sampling time, coinciding with the end of the wave season. It is currently unclear what role waves play in the spawning of these two species, but it would appear that this is an avenue of inquiry worth pursuing. The relatively special wave conditions exhibited at KALA would be instrumental in such a study."

In terms of soil erosion, what impact erosion may, or may not, have had on marine environments is poorly known. The two primary local vectors of erosion that may impact marine environments are colluvial mass wast- ing from sea cliffs and wind erosion of the Kalaupapa Peninsula's fine, dry soils. The north-shore cliffs themselves formed over 1.5 million yr ago as a product of the Wailau Landslide, one of the world's most dramatic erosional events (Clague et al. 1982, Macdonald et al. 1983). Indeed, it is still an active colluvial environment from the base of the cliffs to the coastline. Shifting focus to the Kalaupapa Peninsula itself, a recent study has shown that wind erosion increased due to intensive farming during the Proto-Historic Period (McCoy and Hartshorn 2007). However, consistent northeast trade winds ensure that sediment is deposited in a predictable pattern on the central and western peninsula with presumably little contribution to the leeward marine environment.

Second, although lower sea temperature is known to promote mollusks' growth, unfortunately existing direct measurements of sea surface temperature cannot be used to distinguish variation within the study area. The closest ocean surface buoy is Northern Moloka'i (Station ID no. 51026; $21.35^{\circ} \mathrm{N}$, $\left.156.93^{\circ} \mathrm{W}\right)$, located over 30 miles $(48.3 \mathrm{~km})$ north of the Kalaupapa Peninsula at the transition between the western and eastern coasts; thus it can only give us a general idea of the range of average temperatures in the study area (from January 1993 to November 1996, highest temperatures were in AugustSeptember, $27^{\circ} \mathrm{C}$, and lowest in FebruaryMarch, $23^{\circ} \mathrm{C}$ [source: http://www.ndbc .noaa.gov/station_page.php?station=51026]). Terrestrial-based measures of solar radiation, although not a direct measure of sea surface temperature, show higher levels on the western half of Moloka'i's north coast (400-500 estimated solar calories per $\mathrm{cm}^{2}$ per day) versus the eastern half (300 estimated solar calories per $\mathrm{cm}^{2}$ per day) (source: http://www.hawaii.gov/dbedt/gis). This pattern is likely due to the shading effects of deep eastern valleys, and it is unclear how this may, or may not, impact sea surface temperature.

One potentially good proxy indicator for sea surface temperature in the study area is coral reef development. The eastern coast has 
no substantial reef development, but the west coast has an estimated 40.75 ha (100.7 acres) of coral reef, a rarity on the island's north coast, which certainly suggests warmer conditions, perhaps due to the natural shelter provided by the Kalaupapa Peninsula from colder, northern Pacific waters. Overall, although this indirect evidence of sea surface temperature suggests that the eastern shore may have a cooler temperature regime better suited for mollusk growth, this does not help explain why western limpets are on average larger. Turning to the historical pattern of increased size, climate change effects on sea surface temperature since A.D. 1650 could indeed be influencing the mean size of shellfish, but again this remains untestable with current data.

Third, sea level and shoreline change have been the center of a number of studies across the Hawaiian Islands (see Juvik and Juvik 1998:37-96). However, there is little finegrained data on the study area with the exception of a geological study on the northeast coast of the Kalaupapa Peninsula (Fletcher 1994). The results of that limited study were equivocal on the topic of shoreline change during the time period in question. However, Fletcher (1994:6) did note that although Kalaupapa series soil substrate "probably dates from the glacial lowstand of the sea around $18 \mathrm{ka} .$. the marine conglomerate layer is a product of overwash during the Kapapa Stand about 4 to 5 ka," suggesting that much of the Kalaupapa Peninsula's coastline has been relatively stable in the recent past. In sum, more research is needed to eliminate a shift in the character of the coastline as a factor impacting geographic and temporal patterns observed.

Overall, it seems likely that the naturally higher water turbidity of the eastern shore, and the relative shelter of the western shore from ocean currents and trade winds, is responsible for the observed geographic pattern (see Kay et al. 2005). There are no known ecological factors that can account for the temporal pattern observed; however further work is necessary to definitively eliminate the influence of climate change, geomorphologically active shorelines, and soil erosion.

\section{Harvesting Behavior}

Historical and archaeological data speak to the question of how much harvesting behaviors can account for the patterns observed. To begin, it is important to keep in mind that in Jackson et al.'s (2001) terms, the Kalaupapa region has maintained an aboriginal type of marine harvesting ethic from the prehistoric through to the modern period due to its natural isolation and a unique nineteenthcentury phenomenon that ended commercial enterprises in the area-the establishment of a leprosarium in 1866. However, just before that period, as the Hawaiian Kingdom was drawn in to the global economy, there was an increase in agricultural exports from the Kalaupapa region due to the soaring demand for food in Gold Rush-era markets of California (Ladefoged 1993, McCoy 2005a). However, this was short-lived, probably not lasting long after the market for exported commodities returned to near pre-Gold Rush levels in the early 1850s. Newspaper reports from the time referred to the high agricultural fertility of the area, but no mention was made of the exploitation of marine resources for commercial proposes or otherwise. Today, government agencies oversee the management of natural resources and only small-scale local fishing is allowed.

Nonetheless, if harvesters' shellfish size preference shifted toward larger individuals over time, or consistently favored relatively larger individuals on the western coast, this might explain the geographic and temporal patterns found. However, as noted earlier, the analysis of invertebrates found in Kaupikiawa Cave deposits does not show major evidence for an active shift in the composition of shellfish gathered (Kirch et al. 2003). Naturally, it is difficult to know with certainty that this relative stability in diet breadth extends to choice of size. In terms of modern catches, there are no reported preferences that would help explain this pattern. Further ethnographic work similar to Glazier's (2007) study of modern Hawaiian fishing would certainly help qualify the results in terms of harvesting strategies.

Overall, although all current historic and 
archaeological evidence points to relatively stable harvesting behavior over time, there is a need for more ethnographic research on traditional harvesting.

\section{Demography}

Studies of Hawaiian paleodemography have produced peak Native Hawaiian population estimates ranging from 120,000 , to 400,000 , to over one million (Stannard 1989, Dye and Komori 1992). However, the natural isolation of the Kalaupapa region makes it an ideal location to quantify human population size. The first census of the region, reported by missionaries in 1836, placed local population, probably including the Waikolu Valley, at around 2,700 (The Missonary Herald 1836:18), accounting for roughly $30 \%$ of the island's total population. This is a remarkably high estimate given that the population of the entire Waialua District on $\mathrm{O}^{\prime}$ ahu in 1831-1832 was roughly the same at 2,640 (Schmitt 1973:9, as cited in Kirch and Sahlins 1992:96), and at 130 people per square kilometer (2,700 over $\left.20.8 \mathrm{~km}^{2}\right)$ Kalaupapa would have been extremely more populous than the most sparsely populated areas of Hawai' $i$, such as historic Kahikinui, Maui, at 7.2 people per square kilometer (Kirch et al. 2004). Census data increased in frequency and quality over the next $30 \mathrm{yr}$ as Kalaupapa received its first missionary minister in 1839 (Hitchcock 1841, Somers 1985:25, Ladefoged 1990:9), people began to report to the Mahale land commission (Kirch 2002, Coulter 1931:20), and the region became a home for leprosy patients in 1866 (Greene 1985). Overall, except for the peak in population after 1900 due to the cumulative number of patients sent to Kalaupapa, the general historic trend of depopulation is on the same order as the decrease in Moloka'i's population over the same period. For example, in 1836 island population was estimated at 8,700 , whereas by 1853 it was only 3,607 (The Missionary Herald 1836:18, Coulter 1931:20).

A shockingly high initial estimate by Goodwin (1994:38) of the peak preEuropean contact Native Hawaiian population for the Kalaupapa region of 5,000 to
10,000 assumed a historic-period population decline on the order of $50-90 \%$ due to introduced disease before the first census (Schmitt 1968:15-45, Stannard 1989:12, 5458). However, if one accepts Emory's (1953) population estimate of 10,500 for Moloka'i in 1778 (as cited in Summers 1971), a figure based on a total population of around 300,000 for the Hawaiian Islands, and the first missionary census of 8,700 , then the island experienced only a $17 \%$ population decrease in the first $57 \mathrm{yr}$ after contact (see Summers 1971:3). Summers (1971:3), who supports that scenario, attributed this relatively small decrease compared with that of other islands to Moloka'i "being one of the lesser islands ... [with] poor anchorage ... [and] not frequently visited by white men." Turning back to the Kalaupapa region, if the 1778 population is proportional to the figures in the first census (i.e., with the region accounting for $30 \%$ of the total island population), then using Emory's (1953) estimate, contact population would have been 3,260, much lower than Goodwin's (1994:38) estimate.

Further, it is possible to estimate the overall peak Proto-Historic Period density of population of the study area based on archaeological surface-survey data on habitation sites (see McCoy 2005b for a review of surveys). First, if we consider the number of Proto-Historic Period habitation sites per square kilometer in each individual survey tract we find that the densities of the two lowest-density sections are similar to the published density of 120 structures per square kilometer in the Kahikinui District of Maui (Kirch et al. 2004), and one large survey in the permanently occupied section of the peninsula showed almost three times the density at 330 structures per square kilometer (Kirch 2002), with smaller surveys and surveys of intermittent-use areas showing densities ranging between 600 and 840 structures per square kilometer. From this, the average density was calculated as 279 structures per square kilometer over roughly $0.6 \mathrm{~km}^{2}$. If actual population density is proportional to peak estimated Kahikinui population density (43-57 per square kilometer, an estimate 


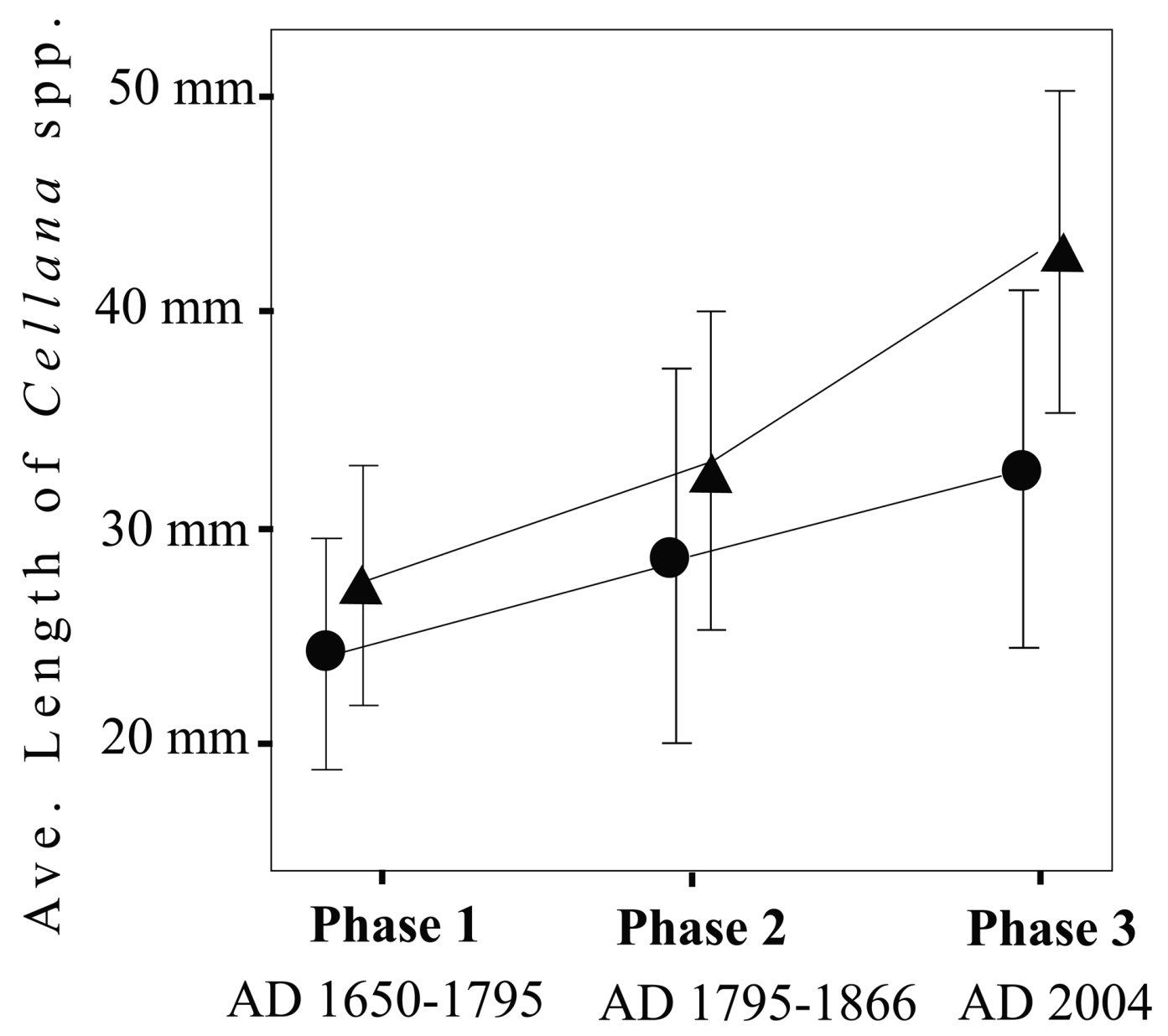

Figure 6. Comparison of average Cellana spp. size, Kalaupapa region, Moloka'i: average length of Cellana spp. in West (triangles) and East (circles) Kalaupapa from Phase 1 (Proto-Historic Period, A.D. 1650-1795), to Phase 2 (Early Historic Period, A.D. 1795-1866), to Phase 3 (A.D. 2004). (Sources: Hughes and Carnevale 2004, McCoy 2006.)

based on a much more complete database of sites), then a range of $99-132$ people per square kilometer would not be unreasonable. Using this figure, total peak Proto-Historic population falls between 2,080 and 2,760 . To bridge the gap between the archaeologicaland historical-based estimates and arrive at a synthetic demographic history, the higher of the Proto-Historic estimates was used to represent 1650 , and the 1750 population was placed at 3,260, assuming little change in the years immediately preceding contact (McCoy 2006).
When viewed in concert, increases in average limpet size and decreases in population over the period between 1650 to the present are closely matched (Figures 6 and 7). In the Proto-Historic Period, population and harvest pressure are assumed to have been at their height, and shellfish were roughly one-quarter to one-third smaller than their current sizes. By the Early Historic Period, human population was conservatively $17 \%$ lower than in the Proto-Historic Period, and average Cellana lengths jumped $18-19 \%$ over the previous period. Today shellfish are even 


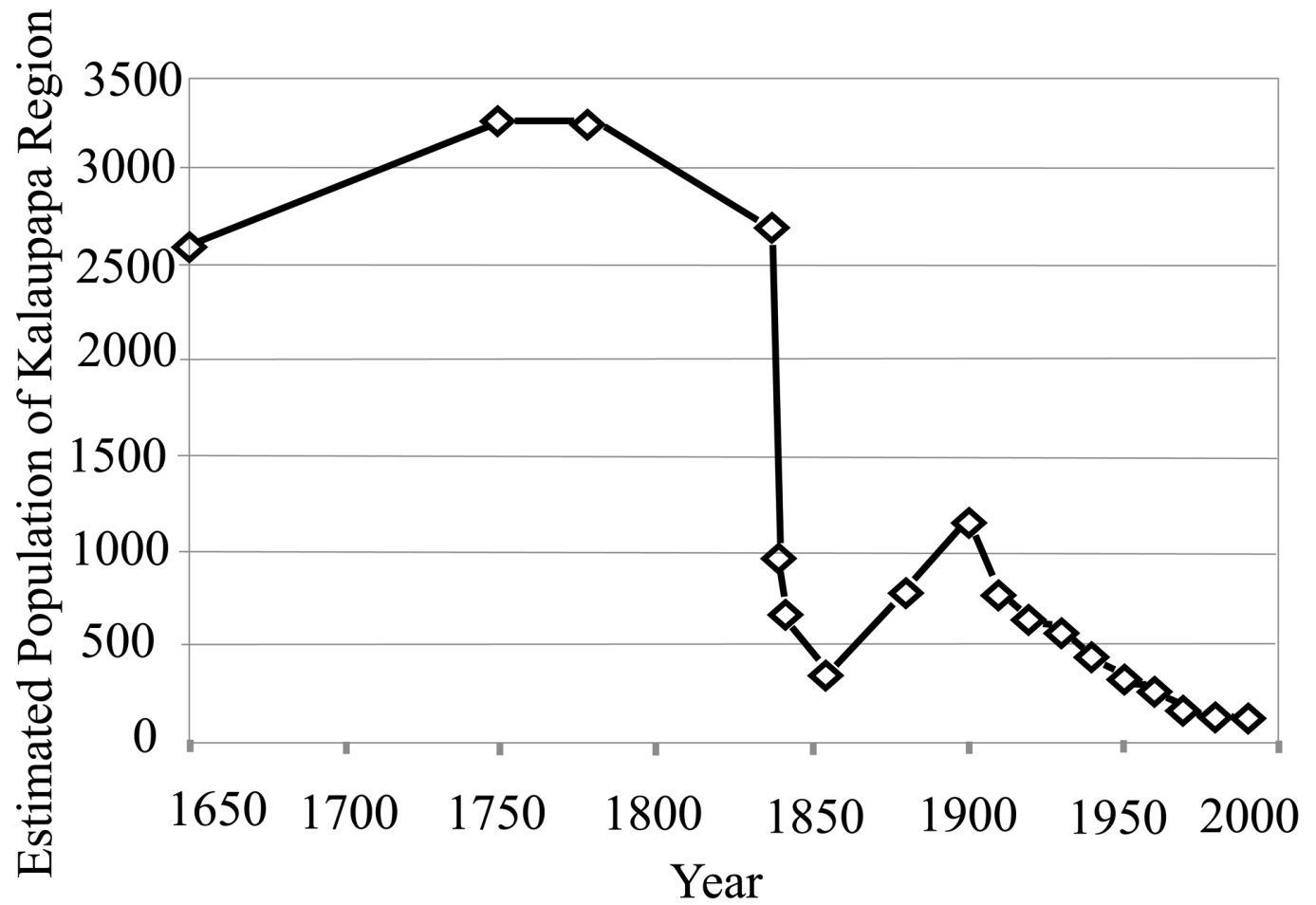

Figure 7. Estimated total population of Kalaupapa region, Moloka'i (A.D. 1650-2000). (Sources: McCoy 2006, U.S. Census Bureau).

larger, up $14-30 \%$ compared with the early historic era. However, when one accounts for the rates of demographic decline and shellfish recovery it appears that "bounce back" was swiftest during the most extreme phase of the demographic crash. In the transition between the Proto-Historic and Early Historic Periods, population declined at a dramatic rate and average shellfish size increased at about $0.4 \%$ per year. In the following decades, population continued to decline slowly with only minimal Cellana size increases (0.1$0.2 \%$ per year). This is consistent with a scenario in which the benefits of lessening harvest pressure are greatest at first, but recovery continues over a long period of time.

Overall, it appears that at the time settlement expanded onto the Kalaupapa Peninsula in 1650, or soon afterward, shellfish exploitation was intense. Indeed, this is consistent with Kirch et al.'s (2003) detailed analysis of
Kaupikiawa Cave (50-60-03-312) that showed initially dense shellfish deposits concurrent with the first occupation of the site (deposits that diminished into the historic period) as well as the possible overexploitation of $C$. exarata. Further, it appears that the increase in average size of Cellana spp. detected at the site by Pearson et al. (1974), but left prudently unexplained, is simply part of this general trend.

\section{CONCLUSIONS}

Overall, modern and archaeological data show the following: (1) Within the Kalaupapa region Cellana spp. are on average slightly larger on the sheltered western coast, suggesting that there are local environmental conditions affecting growth rates. Likely factors include relative shelter from trade winds and ocean currents. More testing is necessary 
to definitively link ecological variables to the observed phenomenon. (2) Cellana spp. in the Kalaupapa region recovered from intensive Proto-Historic Period (A.D. 1650-1795) exploitation at a rate of $+0.4 \%$ per year (average length) concurrent with local demographic collapse during the Early Historic Period (A.D. 1795-1866). This process likely continued at a lesser recovery rate of +0.1 to $0.2 \%$ per year (average length) as human populations stabilized at a low level in the later historic period.

In sum, results suggest that future modern studies should take a microscale approach to describe variation in Cellana spp. populations to account for intraregional variation due to habitat. In addition, future archaeological research should report sizes of intact Cellana spp. with the ultimate goal of determining change over time and attempting to account for the impact of population change on marine resources. Moreover, these results suggest that further research is necessary to determine what impacts prehistoric Hawaiian population growth, and subsequent historicperiod decline, may have had on marine resources.

\section{ACKNOWLEDGMENTS}

I thank Chris Bird, Eric Brown, Maria Carnevale, Jennifer Cerny, Guy Hughes, Walter Kaiama, Patrick Kirch, and the many volunteers who gave their time to measure thousands of 'opibi. Thanks also to anonymous reviewers for their insightful, constructive comments.

\section{Literature Cited}

Alexander, D. 1996. Managing historic resources in an evolving Hawaiian community, Kalaupapa NHP. Cult. Resour. Mag. 19:40-43.

Bird, D. W., and R. L. B. Bird. 1997. Contemporary shellfish gathering strategies among the Meriam of the Torres Strait Islands, Australia: Testing predictions of a central place foraging model. J. Archaeol. Sci. 24:39-63.
Bird, D. W., J. L. Richardson, and P. M. Veth. 2002. Explaining shellfish variability in middens on the Meriam Islands, Torres Strait, Australia. J. Archaeol. Sci. 29:457469.

Bowdler, S. 2006. Mollusks and other shells. Pages 316-337 in J. Balme and A. Paterson, eds. Archaeology in practice. Blackwell Publishing, London.

Canfield, J. E. 1990. Description and map of the plant communities of the Northeast coastal spray zone of Kalaupapa National Historical Park. Cooperative National Park Resources Studies Unit, Honolulu.

Claassen, C. 1998. Shells. Cambridge Manuals in Archaeology. Cambridge University Press, Cambridge, United Kingdom.

Clague, D. A., C. Dao-gong, R. Murnane, M. H. Beeson, A. Lanphere, G. B. Dalrymple, W. Friesen, and R. T. Holcomb. 1982. Age and petrology of Kalaupapa Basalt, Molokai, Hawaii. Pac. Sci. 36:411420.

Coulter, J. W. 1931. Population and utilization of land and sea in Hawaii, 1853. Bernice P. Bishop Museum Press, Honolulu.

Dye, T. S., and E. Komori. 1992. A precensal population history of Hawaii. N. Z. J. Archaeol. 14:113-128.

Erlandson, J. M. 1988. The role of shellfish in prehistoric economies: A protein perspective. Am. Antiquity 53:102-109.

Fletcher, C. H. 1994. Letter report on geology of Kalaupapa, Hawai'i. Pages 1-17, Vol. 2 in C. Goodwin, A Kalaupapa sweet potato farm: Report on archaeological data recovery operations, Kalaupapa Airport Improvement Project, Kalaupapa, Moloka'i, Hawai'i. International Archaeological Research Institute, Inc., Honolulu.

Glazier, E. W. 2007. Hawaiian fisherman: Case studies in cultural anthropology. Wadsworth Publishing Company, Belmont, California.

Goodwin, C. M. 1994. A Kalaupapa sweet potato farm: Report on archaeological data recovery operations, Kalaupapa Airport Improvement Project, Kalaupapa, Moloka'i, Hawai'i. International Archaeological Research Institute, Inc., Honolulu. 
Greene, L. W. 1985. Exile in paradise: The isolation of Hawai'i's leprosy victims and development of Kalaupapa Settlement, 1865 to present. National Park Service, Denver.

Griffiths, R. J. 1980. Natural food availability and assimilation in the bivalve Choromytilus meridionalis. Mar. Ecol. Prog. Ser. 3:151156.

Hirata, J., and L. Potts. 1967. A preliminary study based on midden analysis: Cave 1, Kalaupapa Peninsula, Molokai. Manuscript for Anthropology 521, June 1, 1967, Anthropology Department, University of Hawai'i at Mānoa, Honolulu. Available at Hamilton Library, Hawai'i Pacific Collection, University of Hawai'i at Mānoa, Honolulu.

Hitchcock, H. 1841. Notations made in Molokai Station Reports 1833-1849. Manuscript on file at Mission Houses Museum Research Library, Honolulu. Available at Hamilton Library, Hawai'i Pacific Collection, University of Hawai'i at Mānoa, Honolulu.

Hughes, G. D., and M. Carnevale. 2004. Protocol development-assessing Opibi (Cellana spp.) densities and population structure at Kalaupapa National Historical Park. Progress report on file with and available from the National Park Service.

Jackson, J. B. C., M. X. Kirby, W. H. Berger, K. A. Bjorndal, L. W. Botsford, B. J. Bourque, R. H. Bradbury, R. Cooke, J. Earlandson, J. A. Estes, T. P. Hughes, S. Kidwell, C. B. Lange, H. S. Lenihan, J. M. Pandolfi, C. H. Peterson, R. S. Steneck, M. J. Tegner, and R. R. Warner. 2001. Historical overfishing and the recent collapse of coastal ecosystems. Science (Washington, D.C.) 293:629638.

Jerardino, A. 1997. Changes in shellfish species composition and mean shell size from a Late-Holocene record of the west coast of southern Africa. J. Archaeol. Sci. 24:1031-1044.

Juvik, S. P., and J. O. Juvik, eds. 1998. Atlas of Hawai'i. 3rd ed. University of Hawai' $i$ Press, Honolulu.
Kay, E. A., C. E. Bird, B. S. Holland, and C. M. Smith. 2005. Final report: NPS PICRP Graduate Research Project: Growth rates, reproductive cycles, and population genetics of Opibi from the $\mathrm{Na}$ tional Parks in the Hawaiian Islands. Report on file with and available from the National Park Service.

Kay, E. A., and W. Magruder. 1977. The biology of opihi (October 1975-October 1976). Department of Planning and Economic Development, State of Hawaili, Honolulu.

Kingdom of Hawai'i, Board of Health. 1886. Leprosy in Hawaii: Extracts from reports of presidents of the Board of Health, government physicians and others from official records, in regards to leprosy. Daily Bulletin Stream Printing Office, Honolulu.

Kirch, P. V. 2000. On the road of the winds: An archaeological history of the Pacific Islands before European contact. University of California Press, Berkeley.

. 2002. From the "Cliffs of Keolewa" to the "Sea of Papaloa": An archaeological reconnaissance of portions of the Kalaupapa National Historical Park, Moloka'i, Hawaiian Islands. Archaeological Research Facility, University of California, Berkeley.

. 2005. Archaeology and global change: The Holocene record. Annu. Rev. Environ. Res. 30:409-440.

Kirch, P. V., A. S. Hartshorn, O. A. Chadwick, P. M. Vitousek, D. R. Sherrod, J. Coil, L. Holm, and W. D. Sharp. 2004. Environment, agriculture, and settlement patterns in a marginal Polynesian landscape. Proc. Natl. Acad. Sci. U.S.A. 101:9936-9941.

Kirch, P. V., and S. J. O'Day. 2003. New archaeological insights into food and status: A case study from pre-contact Hawaii. World Archaeol. 343:487-497.

Kirch, P. V., S. J. O'Day, J. H. Coil, M. Morgenstein, K. Kawelu, and S. Millerstrom. 2003. The Kaupikiawa Rockshelter, Kalaupapa Peninsula, Moloka'i: New investigations and reinterpretation of its sig- 
nificance for Hawaiian prehistory. People Cult. Oceania 19:1-27.

Kirch, P. V., and M. Sahlins. 1992. Anahulu: The anthropology of history in the Kingdom of Hawaii. Vol. 2. University of Chicago Press, Chicago.

Klein, R. G. 1999. The human career: Human biological and cultural origins. University of Chicago Press, Chicago.

Krech, S. 1999. The ecological Indian: Myth and history. Norton, New York.

Ladefoged, T. N. 1990. A dryland agricultural system at Kalaupapa, Moloka'i: Archaeological inventory survey, Airport Improvement Project. International Archaeological Research Institute, Inc., Honolulu.

1993. Hawaiian dryland agricultural intensification and the Pacific economy. Pac. Stud. 16:119-131.

Macdonald, G. A., A. T. Abbott, and F. L. Peterson. 1983. Volcanoes in the sea: The geology of Hawaii. 2nd ed. University of Hawai'i Press, Honolulu.

Magruder, W. H., and E. A. Kay. 1983. Growth rates of the limpets Cellana exarata (Reeve) and C. sandwicensis (Pease) in the Hawaiian Islands (Mollusca: Gastropoda). Venus Jpn. J. Malacol. 42:174182.

Manning, E., and E. Neller. In press. Chapters 2-6 in M. D. McCoy, ed. Kalaupapa archaeology: A collection of five surveys in the Kalaupapa National Historical Park. Research Corporation of the University of Hawai'i and National Park Service, U.S. Department of the Interior, Honolulu.

Mannino, M. A., and K. D. Thomas. 2002. Depletion of a resource? The impact of prehistoric human foraging on intertidal mollusc communities and its significance for human settlement, mobility and dispersal. World Archaeol. 33:452-474.

McCoy, M. D. 2002. Report on Kalaupapa Peninsula Archaeological Project (KPAP) fieldwork. Report on file with and available from the U.S. National Park Service and Hawai'i State Historic Preservation Office, Honolulu.

2003. Report on Kalaupapa Peninsula Archaeological Project (KPAP) field- work. Report on file with and available from the U.S. National Park Service and Hawai'i State Historic Preservation Office, Honolulu.

2004. Report on Kalaupapa Peninsula Archaeological Project (KPAP) fieldwork. Report on file with and available from the U.S. National Park Service and Hawai'i State Historic Preservation Office, Honolulu.

- 2005a. The chronology of the Kalaupapa Field System, Moloka'i Island, Hawai'i. J. Polynesian Soc. 114:339-358. 2005 $\mathrm{b}$. The lands of Hina: An archaeological overview and assessment of Kalaupapa National Historical Park, Moloka'i Island. Honolulu, Technical Report 135, Pacific Cooperative Studies Unit of the University of Hawai'i and National Park Service, U.S. Department of the Interior, Honolulu.

. 2006. Landscape, social memory, and society: An ethnohistoric-archaeological study of three Hawaiian communities. Ph.D. diss., University of California, Berkeley.

McCoy, M. D., and A. S. Hartshorn. 2007. Wind erosion and intensive prehistoric agriculture: A case study from the Kalaupapa Field System, Moloka'i Island, Hawai'i. Geoarchaeology 22 (5): 511-532.

Missionary Herald, The. 1836. Mission to the Sandwich Islands. 32:17-21. Boston.

Pearson, R., J. Hirata, L. Potts, and F. Harby. 1974. Test pitting of Cave 1, Kalaupapa Peninsula, Molokai, Hawaii. N. Z. Archaeol. Assoc. Newsl. 17:44-49.

Schmitt, R. C. 1968. Demographic statistics of Hawaii, 1778-1965. University of Hawai'i Press, Honolulu.

Somers, G. F. 1985. Kalaupapa, More than a leprosy settlement: Archaeology at Kalaupapa National Historical Park. National Park Service, Tucson.

Stannard, D. 1989. Before the horror: The population of Hawai' $i$ on the eve of Western contact. Social Science Research Institute, University of Hawai'i, Honolulu.

Summers, C. C. 1971. Moloka'i: A site survey. Bernice P. Bishop Museum Press, Honolulu. 